\title{
Legal Protection of Narcotic Abusers: A Restorative Justice Perspective
}

\author{
Maria Febriana* Slamet Sampurno Soewondo M. Arfin Hamid Wiwie Heryani \\ Faculty of Law, Hasanuddin University, South Sulawesi, Indonesia
}

\begin{abstract}
The increasing of narcotics cases from year to year makes the government must be more introspective related to the distribution of narcotics that comes from outside as well as the distribution that comes from inside. The research uses a socio-legal approach. This approach used to look at legal aspects of social interaction in the communities. The research site is Kediri, East Java province, Indonesia. The results show that the State and Government have an obligation to provide legal protection against narcotics abusers. Abusers are the citizen who must be fulfilled their rights. The appropriate treatment for a narcotics abuser is getting medical and social rehabilitation. By medical rehabilitation, narcotics abusers can recover from their dependence on narcotics and become a healthy person. Implementing restorative justice to narcotics abusers is not to bring narcotics abusers who have been arrested directly using narcotics without rights or against the law into the legal process, but place them in a place of medical and social rehabilitation. In realizing restorative justice, there are obstacles to narcotics crime includes no regulation equal to the law on the regulation of restorative justice especially for narcotics abusers as victims which can be used as guidelines by law enforcers to enforce restorative justice for narcotics abusers.
\end{abstract}

Keywords: Criminal Law; Drugs; Narcotics; Restorative Justice

DOI: $10.7176 / \mathrm{JLPG} / 88-09$

Publication date: August $31^{\text {st }} 2019$

\section{Introduction}

Narcotics crime becomes increasingly high and complex, expecting Indonesia to be careful and alert to the abuse of Narcotics which can threaten the nation's generation. As a constitutional State, Indonesia must firmly regulate every citizen who commits abuse of narcotics. The minimum prison sentence and a very large fine will be imposed on every Indonesian citizen who is proven to have committed a criminal offense in the narcotics; and the most severe is death penalty that will be imposed on narcotics offenders.

In Indonesia, the increasing of narcotics cases from year to year makes the government must be more introspective related to the distribution of narcotics that comes from outside as well as the distribution that comes from inside. In 2018, the National Narcotics Agency of the Republic of Indonesia has revealed 914 (nine hundred fourteen) narcotics cases and its precursors involving 1.355 (one thousand three hundred fifty-five) suspects and confiscating 3.4 tons methamphetamine, 1.39 hashish, 469.619 ecstasy pills with 83 (eighty-three) drug syndicates. ${ }^{1}$

Narcotics business is a very promising and lucrative business, it spreading not only in big cities like Jakarta but also has spread to the suburbs even to the corners of the countryside, one of them is Kediri, a city far from the bustle of the big city, its development is so fast and as if no someone to be able to prevent and its circulation with a total of 56 (fifty-six) narcotics cases in the last 3 (three) years. ${ }^{2}$

It is proportional to the increasing of narcotics circulation, narcotics abusers are also increasing, both as narcotics addicts and victims of narcotics abuse. For this fact, who is to blame, a state, society or individuals as narcotic abusers. Whether blaming each other will solve the problem of narcotics circulation and narcotics abusers?

Resolving problems for narcotic abusers by punish them in the prison will further add to the concern that abusers will learn to circulate narcotics to more skilled narcotics inmates. For this reason, a mutual understanding between law enforcer is needed, by rehabilitate narcotics abusers in representative locations.

In applying the principles of restorative justice ${ }^{3}$ for narcotics abusers must really considers the principles of of restorative justice as well as the rules and requirements of the internal institutions of Law Enforcers. Restorative justice is very needed for narcotics abusers because they are victims who must be healed and saved so as not to fall deeper into narcotics circulation, because it does not rule out a narcotics abuser can become

\footnotetext{
${ }^{1}$ The Indonesian National Narcotics Agency. 2018. Press Release at the end of 2018. Jakarta: BNN Cawang-Jakarta Timur, 20 December 2018.

${ }^{2}$ Data obtained from the District Court of Kediri in 2016-2018

${ }^{3}$ Muhammad Irwan, et al. 2018. The Role of Judges in Realizing Justice: A Criminal Justice Perspective. Journal of Law, Policy and Globalization, Vol. 76, 114. Compared to Bambang Waluyo, 2016, Desain Fungsi Kejaksaan pada Restorative Justice, Jakarta: Raja Grafindo Persada, p. 42-43
} 
circulator or dealers. Restorative justice for narcotics abusers is the rehabilitation properly through medical and social rehabilitation as soon as possible, not a long process and ends in prison.

\section{Method of Research}

The research uses a socio-legal approach. ${ }^{1}$ This approach used to look at legal aspects of social interaction in the communities. The research site is Kediri, East Java province, Indonesia. It is an analytical-descriptive research to explore the legislation relating to legal theories as research object.

\section{The Essence of Legal Protection against Narcotics Abusers}

Every Indonesian citizen has the right to legal protection and health, including narcotics abuser. As narcotics abusers, they are performer as well as a victim who suffers pain. The healing and treatment of narcotics abuser as a sick person is to get medical and social rehabilitation so that they can heal and be as healthy as ever.

Basically, the implementation of medical rehabilitation consists of a detoxification and stabilization program. Recovery activities in an integrated manner so that narcotics abusers can adapt and function by biopsycho-socio-spiritual in the community with a method of Therapeutic Community (TC), followed by vocational therapy and socialization. The State and the government are obliged to provide legal protection for its citizens and do not rule out the possibility of providing legal protection against narcotics abusers.

As results of the questionnaire that was distributed to law enforcement officers in Kediri consisting of police, prosecutors and judges obtained from the investigations and information obtained at the hearing, many factors that make someone use narcotics, including:

\subsection{Family influence}

Basic education comes from families, including about religious education. The family has a very important role to create the character of their family members. Early religious education for all family members can be used as a solid foundation so that later for every family member who will enter the community is not easily influenced by negative things. A good religious education will produce good morals for each family member so that they are able to choose what is good and bad. Early education about narcotics for each family member will be very helpful so that each family member is not affected to use it, because they already knows the negative effects on health, and even the legal consequences when someone uses narcotics without rights or against the law.

Parents must keep and provide full control over each family member, especially towards their children, especially in this sophisticated era, the effect of unlimited social media, facilitate information about narcotics, how to use and how to get it. In addition, intense communication between family members and openness between them will fortify all family members from the bad effects of narcotics. Relationships between family members who are less harmonious (broken home) can make a person easily discouraged and frustrated that ultimately trapped into the bad effect of narcotics.

If there is one family member to be a user or narcotics abusers and even narcotics dealers, ${ }^{2}$ then it is ruled out can influence other family members to involve in the narcotics abusers, whether as users or narcotics abusers can even become narcotics dealers and trapped in the dark circulation of narcotics.

\subsection{Personal Matter}

The self-curiosity and desire to use narcotics, began from the trying what is done by other people who have used narcotics and eventually become addicted to use it unconsciously or thinking long about the bad consequences for health in the future which can lead to addiction and even death or legal consequences that will be caused if using narcotics without rights or against the law. Labile personality, not good and easily influenced by others will make a person more easily fall into the abuse of narcotics.

There are assumption that narcotics can be used as a stimulant for workaholic peoples as a stimulant-giving effect (increasing excitement in work) so that they can continue to work without feeling tired and for themselves who have problems or too heavy life burdens, narcotics are used as a place to escape from problems, boredom, bitterness and too heavy life burden. There are assumptions that narcotics can be used as a depressant effector that makes the user feel quiet, in addition it can be used to entertain them and enjoy their life as a pseudo life.

\subsection{Environmental impact}

Environmental can also be a factor to use narcotics. A negative and unhealthy environment in their residence plays an important role for someone to use narcotics, for example the social environment that has

\footnotetext{
${ }^{1}$ Amiruddin and Zainal Asikin, 2012, Pengantar Metode Penelitian Hukum, Jakarta: Raja Grafindo Persada, p. 34

${ }^{2}$ Arhjayati Rahim, et al. 2017. Legal Analysis of Formulation of Child Narcotics Dealer. Journal of Law, Policy and Globalization, Vol. 58.
} 
a hobby of having fun and always comes to night entertainment and likes to drink alcoholic drinks, these two things are the gateway to abuse narcotics. Hence, inability to adapt to the environment and not daring to face pressure from the environment or bad social groups will influence someone to enter the negative environment.

\subsection{Financial factor}

More financial without supervision from parents and family can be trigger and encourages someone to realize their curiosity and try to use narcotics. Someone who is economically capable but lacking enough attention from the family is more likely to fall into narcotics. And for someone who is financially lack, narcotics can be a field or source of livelihood for profit and get money by selling or circulating narcotics to people who need narcotics because it promises big profits. Difficulties looking for work can also lead to a desire to work as a narcotics supplier.

\subsection{Ease to circulate narcotics}

Last but not least, the ease to circulate narcotic and inexpensive price make more people getting narcotics as well as information about narcotics that can easily be accessed via the internet.

Without looking for the factors and person's background using narcotics, whether it is tries (in personal) or invite/influences of others, the State and the government must be present to provide legal protection and healing for narcotics abusers. The State and the government must guarantee narcotics abusers, addicts and victims to obtain medical assistance and information needed in order to minimize the risks faced by narcotics abusers, it can be done by placing them in medical and social rehabilitation facilities as designated and determined by the Ministry of Health of the Republic of Indonesia and the Ministry of Social Affairs of the Republic of Indonesia for abusers who are facing legal proceedings as well as those that have been decided by the court and also for those who voluntarily and independently report themselves to the Tax Payer Recipient Institution (so called, IPWL) to participate in medical and social rehabilitation as narcotics abusers.

By attending medical and social rehabilitation for narcotics abusers, it is expected the physical of narcotics abusers can recover from the addiction to narcotics, no longer have dependency on narcotics and after participating in rehabilitation, they will be able to return and be accepted in community properly and no longer repeat their action at a later and prevent others from the possibility of committing a similar act of abusing narcotics.

Data on the narcotics abusers in Kediri over a period of 3 (three) years, precisely between 2016 and 2018 , and also the detailed data were obtained by collecting 13 samples randomly from 13 cases of narcotic abusers (Table 1).

Table 1. Data of narcotics case and abusers

\begin{tabular}{ccc}
\hline Year & Cases & Narcotics Abusers \\
\hline 2016 & 5 & 8 \\
2017 & 16 & 17 \\
2018 & 24 & 26 \\
Total & 45 & 51 \\
\hline \multicolumn{2}{c}{ Source: District Court of Kediri in period 2016-2018 }
\end{tabular}

As data presented above, there is no full commitment from the law enforcers, namely investigators, prosecutors and judges in decide claims by prosecutors and decisions by judges and requests for assessments in the National Narcotics Agency by investigators. There are demands that do not conduct medical or social rehabilitation for narcotics abusers, whereas the narcotics abusers should be prosecuted for medical or social rehabilitation as well as a decision which does not order medical or social rehabilitation for abusers who are undergoing the process the law when the narcotics abusers can be decided and ordered to medical or social rehabilitation.

Lack of awareness from law enforcers to implement existing laws and regulations regarding the handling of narcotics abusers and the utilization of medical and social rehabilitation for abusers that can be proven as victims of narcotics abuse, so that an abuser who should get medical and social rehabilitation have to prisoned at penitentiary.

The data on narcotics abusers' cases, they who undergone medical and social rehabilitation in the penitentiary, both in Penitentiary Class IIA in Kediri and the Youth Narcotics Penitentiary Class IIA in Madiun. Penitentiary is not a place to rehabilitate or recovery of a narcotics abuser. According to the author, it is very ineffective and inefficient to place abusers in medical and social rehabilitation.

Narcotics abusers must be rehabilitated in a designated place or reference to rehabilitate them, such as medical and social rehabilitation, by rehabilitate them in the right place will provide maximum healing for the abuser, strict supervision for the healing process, the availability of experts in their fields and facilities and infrastructure available to support the rehabilitation process that has been available in full will help the healing 
process and recovery more quickly.

As previously it has been imaged that a narcotics abuser is someone who is in a state of illness. People who are sick should be treated immediately in order to recover. How would it be if a sick person was gathered with a person whose illness was more severe, not a cure would be obtained that the pain would be worse than before, from an abuser to supplier even dealer. By the mixing of narcotics abusers with other narcotics criminal offenses (other than abusers), it is feared that they will be able to form a new community or network, so that after free they can develop narcotics circulation with new networks. In addition, by the mixing of narcotics abusers with other narcotics criminal detainees (outside of abusers) will cause interaction and build communication with other narcotics crimes, it is not uncommon for an abuser who undergoes rehabilitation after being released from the prisoner, it is feared that it will gain more knowledge, no longer being an abuser but becoming a supplier or courier even as dealer or producer.

\section{Implementing Restorative Justice against Narcotic Abusers}

The principle of restorative-justice cannot be interpreted as a method of terminating a criminal case, but to fulfill a sense of justice ${ }^{1}$ for all parties involved in criminal cases through efforts that involve victims, perpetrators and local communities as well as investigators as mediators, while the settlement of criminal offense can be done in a peace agreement and right revocation to sue from the victim, requires the appointment of a judge through the public prosecutor to abort the authority to sue from the victim and public prosecutor.

The application of restorative justice for narcotic abusers can be done by considers several things: First, as a form of legal protection for narcotic abusers, the State and government are obliged to protect every citizen, including narcotic abusers; Second, respecting human rights of a narcotics abuser; and not contradict with the rule of law. ${ }^{2}$ Furthermore, based on the typology of victims as identified according to the circumstances and their status, includes: ${ }^{3}$

a. Unrelated victims, is unrelated victims as all with the perpetrators and become victims because they have potential to it;

b. Provocative victims, is a person or victim caused by the role of victim to trigger the crime;

c. Participating victims, is a person who does not do anything but with his/her attitude encourages them to be a victim;

d. Biologically weak victims, those who have physical weaknesses that cause them to become victims;

e. Socially weak victims, those who have a weak social position that causes them to be victims;

f. Self-victimizing victims, those who become victims because of crimes they have committed themselves. As a narcotic abuser can be referred to as a self-victimizing victim, because an abuser in addition to being a perpetrator is also a victim of a crime.

The State must actively participate in resolving fairly to provide recovery to the initial condition for victims who are narcotics abuser through rehabilitation programs, namely medical and social rehabilitation. The State must be present to provide a protection fairly for narcotics abusers, legal protection in the process to the rehabilitation of abusers through the provision of adequate rehabilitation facilities and infrastructure.

Law enforcers consisting of investigators, prosecutors and judges cannot deviate from the validity of Lex superior derogat legi inferior principle where higher regulations override the lower (hierarchical principle). It shows that the application of restorative justice for narcotics abusers must be stated clearly in the law as a basis for law enforcement officials in acting to do restorative justice for narcotics abusers.

Internally, the Chief of Indonesian National Police issued a Circular Letter No. SE/8/VII/2018 concerns the application of restorative justice. By the issuance of this circular, it does not rule out the possibility of a narcotics abuser to apply restorative justice. The lawsuit parties in narcotics abuse are narcotics abusers and as victims and the State, the State as a reporting party that reports narcotics abusers and those reported are abusers. The lawsuit parties are simpler compared with other offense, because there are no victims from other parties, narcotics abusers are not burdened with responsibility to the victims and there is no compensation for the victims and does not have the impact of social conflict. In this condition, what is really needed is a recovery for the perpetrators and also victims of narcotics abusers.

By applying restorative justice for narcotics abusers, it is expected that they can provide maximum results for narcotics abusers to recover from their dependence on narcotics and become healthy people as before, in addition by applying restorative justice for narcotics abusers, several things below can be achieved, as follows:

a. Reducing overcapacity in the Penitentiaries, abusers no longer occupy prisons but immediately get rehabilitation both medical and social in IPWL that have been designated by the Ministers of Health and Social Affairs;

\footnotetext{
${ }^{1}$ Achmad Ali, 1996, Menguak Tabir Hukum (Suatu Kajian Filosofis dan Sosiologis), Chandra Pratama, Jakarta

${ }^{2}$ Mahrus Ali (ed), 2013, Membumikan Hukum Progresif, Yogyakarta: Aswaja Pressindo, p. 62

${ }^{3}$ Rena Yulia. 2010. Viktimologi, Yogyakarta, Graha Ilmu. pp. 53-54
} 
b. Reducing case arrears, by the presence of restorative justice for narcotics abusers, narcotics abuser cases are no longer through the prosecution and trial process;

c. Imbalance the law enforcement officers with the development of narcotics abuse cases, it is expected that the application of restorative justice for narcotics abusers can reduce the number of cases;

d. Imposed costs used for the investigation, prosecution and trial process for narcotics abuse cases can be diverted its use to the maximum extent possible to be used to do medical and social rehabilitation for someone who can be called as narcotics abuser;

e. Brings a better impact on changes in the way of thinking of the Indonesian people towards the criminal law enforcement process, from the prosecution of narcotics abusers to recovery for narcotics abusers who are also victims while still considers the values of justice in society and legal certainty about the process and results.

At practical level, needed time since the narcotics abusers are arrested by the Police officers of Kediri until they are placed in rehabilitation is 11 (eleven) days. This is a short time so that the abusers can immediately be rehabilitated without waiting for a long time. For medical and social rehabilitation, it can be adjusted to the level of dependency experienced by narcotics abusers regarding the duration of rehabilitation.

The important things to be considered in the process of applying restorative justice for narcotics abusers includes: the first, there is a common perception and commitment between law enforcement officers and relatedagencies in the implementation of restorative justice for narcotics abusers. In this case, the narcotics abusers are people who use narcotics without rights or against the law as well as victims and perpetrators, an abuser can be said to be someone who is in a state of illness and must get treatment to recover, by placing him in a place of medical and social rehabilitation. The State and government are obliged to take part and participate in protecting and providing healing for citizens.

Last and not least, in terms of providing medical rehabilitation can be applied in-patient and out-patient depending on the conditions and needs of the narcotics abusers. Recommendations on the assessment results as made by the Integrated Assessment Team must be truly made based on the conditions and needs of the narcotics abusers, so that they can provide complete healing and maximum results and effective for narcotics abusers that are free from the snare of narcotics. Such recommendations can be a basis for the decision by the Head of District Court and in this decision has been written a place for medical and social rehabilitation for the abuser.

\section{Conclusion}

The State and government have obligation to provide legal protection against narcotics abusers. Abusers are citizen who must be fulfilled their rights. A narcotics abuser is a perpetrator as well as a victim of a criminal offense. For this reason, all law enforcement officials and all elements of society must have a similar understanding and perspective that narcotics abusers are victims not perpetrators of crime. The appropriate treatment for a narcotics abuser is getting medical and social rehabilitation. By medical rehabilitation, narcotics abusers can recover from their dependence on narcotics and become a healthy person.

The application of restorative justice to narcotics abusers is not to bring narcotics abusers who have been arrested directly using narcotics without rights or against the law into the legal process, but place them in a place of medical and social rehabilitation. In realizing restorative justice, there are obstacles to narcotics crime includes no regulation equal to the law on the regulation of restorative justice especially for narcotics abusers as victims which can be used as guidelines by law enforcers to enforce restorative justice for narcotics abusers.

\section{References}

Achmad Ali, 1996, Menguak Tabir Hukum (Suatu Kajian Filosofis dan Sosiologis), Chandra Pratama, Jakarta. Amiruddin and Zainal Asikin, 2012, Pengantar Metode Penelitian Hukum, Jakarta: Raja Grafindo Persada.

Arhjayati Rahim, M. Said Karim, Muhadar, Syamsuddin Muchtar. 2017. Legal Analysis of Formulation of Child Narcotics Dealer. Journal of Law, Policy and Globalization, Vol. 58.

Bambang Waluyo, 2016, Desain Fungsi Kejaksaan pada Restorative Justice, Jakarta: Raja Grafindo Persada. Mahrus Ali (ed), 2013, Membumikan Hukum Progresif, Yogyakarta: Aswaja Pressindo.

Muhammad Irwan, Slamet Sampurno Soewondo, M. Syukri Akub, Wiwie Heryani. 2018. The Role of Judges in Realizing Justice: A Criminal Justice Perspective. Journal of Law, Policy and Globalization, Vol. 76, 114.

Rena Yulia. 2010. Viktimologi, Yogyakarta, Graha Ilmu.

The Indonesian National Narcotics Agency. 2018. Press Release at the end of 2018. Jakarta: BNN CawangJakarta Timur, 20 December 2018. 